\title{
Analysis of Images Produced by Smoky Makeup Using a Color Image Scale for Female Eyes
}

\author{
Min-Kyung Kim \\ Department of Beauty Care, Jangan University, Hwaseong-si, Gyeonggi-do, Korea
}

Corresponding author: Min-Kyung Kim, Department of Beauty Care, Jangan University, 1182 Samcheonbyeongma-ro, Bongdam-eup, Hwaseong-si, Gyeonggi-do 18331, Korea

Tel.: +82 312993316

Fax: +82 312993612

Email: minkyung4567@jangan.ac.kr

Received June 3, 2021

Revised July 20, 2021

Accepted August 4, 2021

Published September 30

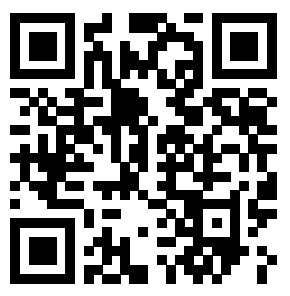

\begin{abstract}
Purpose: In order to analyze the images to be produced by tone variations in the smoky makeup, according to the forms of eyes, this study evaluated them by applying adjective image scales as the tool for quantitative assessment. Methods: By categorizing female eyes into seven forms, we examined images in which the tones of smoky makeup changed across five stages, ranging from the highest to the lowest brightness. We varied the positions of the eyes on the image map. Results: The eyes without makeup have different images, depending on the forms of eyes: standard eyes with folded eyelids and large eyes have dynamic and soft images, while drooping eyes have static and stiff images. The positions of eyes were varied on the image map. Although the standard eyes which were evaluated as having the most soft images could express very various images, by changing the tones of the smoky makeup, those which could be expressed by drooping eyes were very restricted, even though the tones of the smoky makeup were changed. Conclusion: It is consequently found that there are large variations in image areas to be produced by makeup, and that the image map is a tool useful for systematically analyzing the dynamic characteristics of variations in eyes' images, as the tones of makeup are changed.
\end{abstract}

Keywords: Color, Color image scale, Eye shape, Image, Smoky makeup

\section{Introduction}

사람의 얼굴 이미지는 얼굴형, 입술, 코, 눈, 눈썹과 같은 형태적 특성에 영향을 받는다. 얼굴 이미지는 눈 형태에 의하여 감성변화 가 크기 때문에 아이 쉐도우 컬러와 톤을 조정하여 형태적 특징을 강 조, 수정, 보완하여 개인의 고유한 이미지를 만드는데 효과적으로 활 용한다(Ji \& Kim, 2016). 아이 쉐도우 테크닉 중 하나인 스모키 메 이크업은 아이 라이너와 아이 쉐도우를 이용하여 눈 주위를 진하 고 어둡게 연출하는 화장기법이다(Park et al., 2007; Hong \& Lee, 2009). 스모키 메이크업은 눈을 강하게 보이게 하므로 약한 이미지 를 가진 사람이나 모델들, 그리고 아이돌 가수들에게 대표적 메이크 업으로 활용되고 있다(Kim, 2009; Kim, 2018). 스모키 메이크업은 1990 년대에는 부담스러운 이미지로 인하여 비대중적이었으나 2000 년대부터 대중적으로 바뀌었다. 특히 2007년도 전후로 K-Pop의 아 이돌 그룹 가수들의 활용 폭이 증가하고 있고, 방탄소년단 역시 스 모키 메이크업을 하면서 점차 확산되어 현재는 대중적인 아이 메이
크업의 트렌드가 되었다. 메이크업 컬러에 따라 다양한 이미지가 연 출되는 만큼 아이 쉐도우 컬러에 따라 다양한 이미지로 표현할 수 있 었다(Cho, 2018). 특히 스모키 메이크업은 주로 어둡고 무거운 톤 을 많이 사용함으로 특정한 이미지로 연출하기 위해서 얼굴의 형태 적 특성(눈, 코, 입, 및 눈썹의 모양, 얼굴형, 피부색 등)과 패션, 연 출의 목적 등을 종합적으로 고려한다. 특히 눈의 형태는 사람에 따라 다르기 때문에 연상되는 이미지도 다양하다. 일반적으로 눈의 형태 는 큰 눈(big eye), 작은 눈(small eye), 처진 눈(down-turned eye), 올라간 눈(up-turned eye) 등 다양한 눈의 형태를 가지고 있으며 쌍 겹 유무에 따라 나눌 수 있다. 메이크업에 의한 이미지 연출은 대부 분 아티스트들의 감각과 경험에 의존하고 있다. 스모키 메이크업 이 미지 연출 효과를 체계적으로 연구한 논문들은 많지 않으며, 스모키 메이크업 패턴보다는 패션(의상)과 연계하여 얼굴 이미지에 대한 내 용이 대부분이었다(Yang, 2010; Kim \& Choi, 2012; Oh \& Choi, 2011; Hong \& Lee, 2009). 또한 연구의 대부분은 메이크업 기법들 을 적용하였을 때 연출되는 대상의 전체적인 이미지 평가와 관련된 
것들이 대부분이었다(Kim \& Ryu, 2011; Choi et al., 2010; Kim \& Choi, 2012). 눈의 고유한 특성에 관한 언급은 거의 없이 연구가 진 행되었다. 따라서 눈의 형태에 따라 갖는 고유한 이미지에 대하여 분 석하고, 스모키 메이크업에 의한 이미지의 변화를 체계적인 분석방 법을 사용하여 정립할 필요가 있었다. 현재 컬러 이미지 스케일은 감 성반응을 보다 구체적이고 과학적 접근방법으로 이미지화 시키는데 패션, 미용, 디자인, 인테리어분야에서 유용한 도구로 활용되고 있다 (Kobayashi, 1981; Lee \& Lee, 2006; Lee et al., 2012). 그렇게 다 양분야에서 색채가 지닌 특정한 이미지(감성)를 측정하기 위하여 개 발된 컬러 이미지 스케일을 활용하여 스모키 메이크업을 적용한 각 각의 눈에 이미지 해석 적용이 가능할 것으로 판단하였다. 따라서 본 연구에서는 7 가지 눈 형태에 스모키 메이크업의 톤을 고명도에서 저 명도까지 5 단계로 변화시켜 일러스트레이션을 만들어 눈 고유형태 에 따른 이미지 반응을 조사하였다. 그리고 형용사 이미지 맵이 메이 크업 이미지 분석에 유용하게 활용할 수 있는 도구임을 입증하고자 한다.

\section{Methods}

\section{1. 연구대상}

미용학과에 재학 중 인 19-25세의 여대생 297명, 35-42세의 전 문가 45 명을 대상으로 스모키 메이크업 일러스트레이션들을 보고 연상되는 이미지에 해당하는 형용사나 명사 등의 감성언어를 기재하
도록 하였다. 수집된 감성언어들은 유사 의미 별로 분류하여 빈도수 가 높은 이미지 형용사를 각각의 일러스트레이션의 대표적인 이미지 로 도출하였다.

\section{2. 자극물 제작방법}

여성의 대표적인 눈 모양으로 7가지 형태(표준형 눈, 처진 눈, 올 라간 눈, 쌍겹의 작은 눈과 큰 눈, 외겹의 작은 눈과 큰 눈)를 선정하 였다. 사람의 이미지는 얼굴 형태와 피부 타입 등 다양한 인자들에 의하여 영향을 받기 때문에 이들의 영향을 배제시키고, 순수한 눈의 이미지만을 평가하기 위하여 눈 만을 그린 패턴북의 일러스트레이션 을 사용하였다(Kim \& Hong, 2010). 스모키 메이크업 일러스트레이 션은 실제 사람의 눈과 비슷한 크기의 비율을 사용하였다.

표준 눈의 제원은 가로 $4 \mathrm{~cm}$, 세로 $1.8 \mathrm{~cm}$, 눈과 눈 사이 거리 4 $\mathrm{cm}$, 눈썹과 눈의 사이(눈의 제일 높은 부위와 수직 선상의 길이) 1.5 $\mathrm{cm}$ 였다. 이러한 표준형을 바탕으로 컴퓨터 그래픽 작업을 통해 6 가 지 눈의 형태(처진 눈, 올라간 눈, 작은 눈과 큰 눈, 외겹의 작은 눈과 큰 눈)를 제작하였다. 눈 꼬리가 올라간 눈의 크기는 가로 $4 \mathrm{~cm}$, 세 로 $1.8 \mathrm{~cm}$ 이고, 눈 꼬리는 20 도 올라 가도록 제작하였다. 제작된 7 가지 형태의 눈에 색연필과 아이 쉐도우를 사용하여 고명도(노 메이 크업)부터 시작하여 톤을 점차적으로 저명도로 표현한 5 가지 톤의 스모키 메이크업 일러스트레이션(노 메이크업, 중명도의 소프트 스 모키, 라인 스모키, 브라운과 블랙 톤의 저명도 면적 스모키)을 제작 하였다(Table 1). 전문가와 비전문가에서 도출된 10 가지 그룹의 감 성 이미지는 각각의 눈에 스모키 메이크업을 적용하여 도출한 결과

Table 1. Stimulus material consisted of 7-type eyes observed

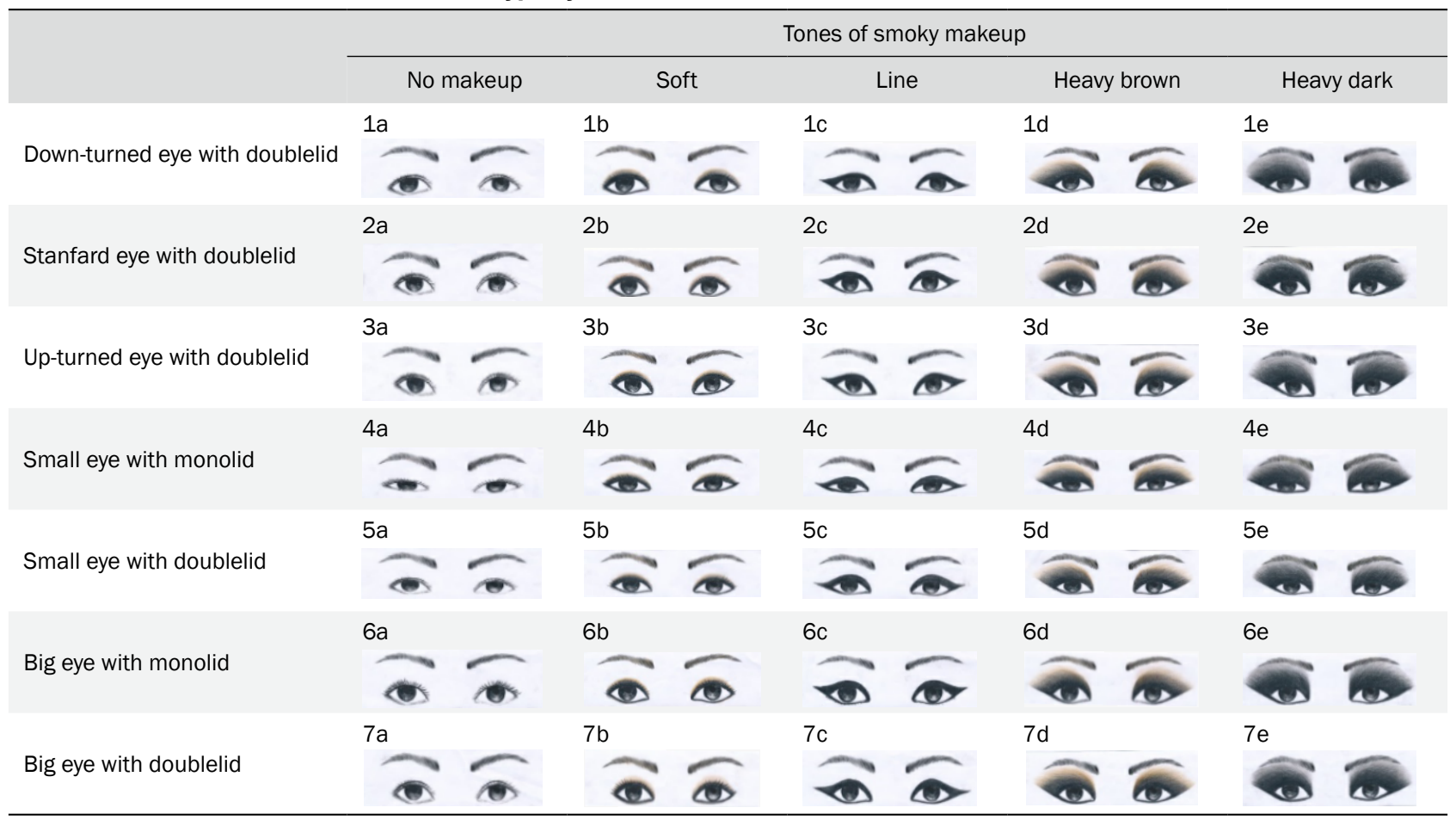


를 Table 2에 정리하였다.

\section{3. 분석방법}

7 가지의 눈의 형태에 스모키 메이크업 5 가지의 톤 변화에 대하 여 수집된 대표적 감성언어들을 컬러 이미지 스케일에 적용하여 이 미지 포지셔닝 맵을 작성하였다. 본 연구에서는 한국인의 고유한 색 채 감성을 반영한 컬러 이미지 스케일을 사용하였다(Figure 1). 각각 의 일러스트레이션에 대해 참여자들로부터 수집된 감성언어들은 조 사에 참여한 학생들과 전문가 간의 차이가 크지는 않았다. 그러나 비 전문가의 인원이 많으므로 반영비율을 적용하여, 전문가와 비전문 가들에게 도출된 감성언어는 5 대 5 로 적용하여 조사하였다. 도출한 감성 언어는 평균적으로 높은 비율의 언어 10 가지로 추출하였다. 본 연구는 피시험자들이 색맹과 인지 장애가 없는 대상을 선별하여 조 사하였으며, 헬싱키윤리기준과 임상시험기준을 준수하였으며 보건 복지부 지정 공용기관인 생명윤리위원회의 승인을 받았다(승인번호:
P01-201807-11-002).

\section{Results \& Discussion}

1. 쌍겹의 눈꼬리가 올라간 눈과 내려간 눈의 감성 이미지

표준눈 $(2 \mathrm{a}-2 \mathrm{e})$ 을 기준으로 쌍겹의 눈꼬리가 처진 눈(1a-1e)과 올 라간 눈( $3 \mathrm{a}-3 \mathrm{e})$ 일러스트에 5 가지 스모키 메이크업 톤을 변화시켜 연상되는 이미지를 Figure 2에 도시하였다.

표준눈(2a)은 '맑은(41\%)', '밝은(26\%)'이미지와 더불어 '청순한' 느 낌을 갖는 것으로 평가되었다. 세미 스모키 메이크업을 한 표준 눈 (2b)은 '자연스러운(27\%)'과 '친근한(21\%)'등의 '네츄럴한' 이미지를 갖고, 라인 스모키 메이크업(2c)은 '그윽한(24\%)' , '심플한(23\%)' 느 낌이 주된 이미지였다. 더불어 '정돈된' 등의 의견으로 전체적으로 ' 은은한' 이미지로도 평가되었다. 브라운 톤의 면적 스모키를 한 표

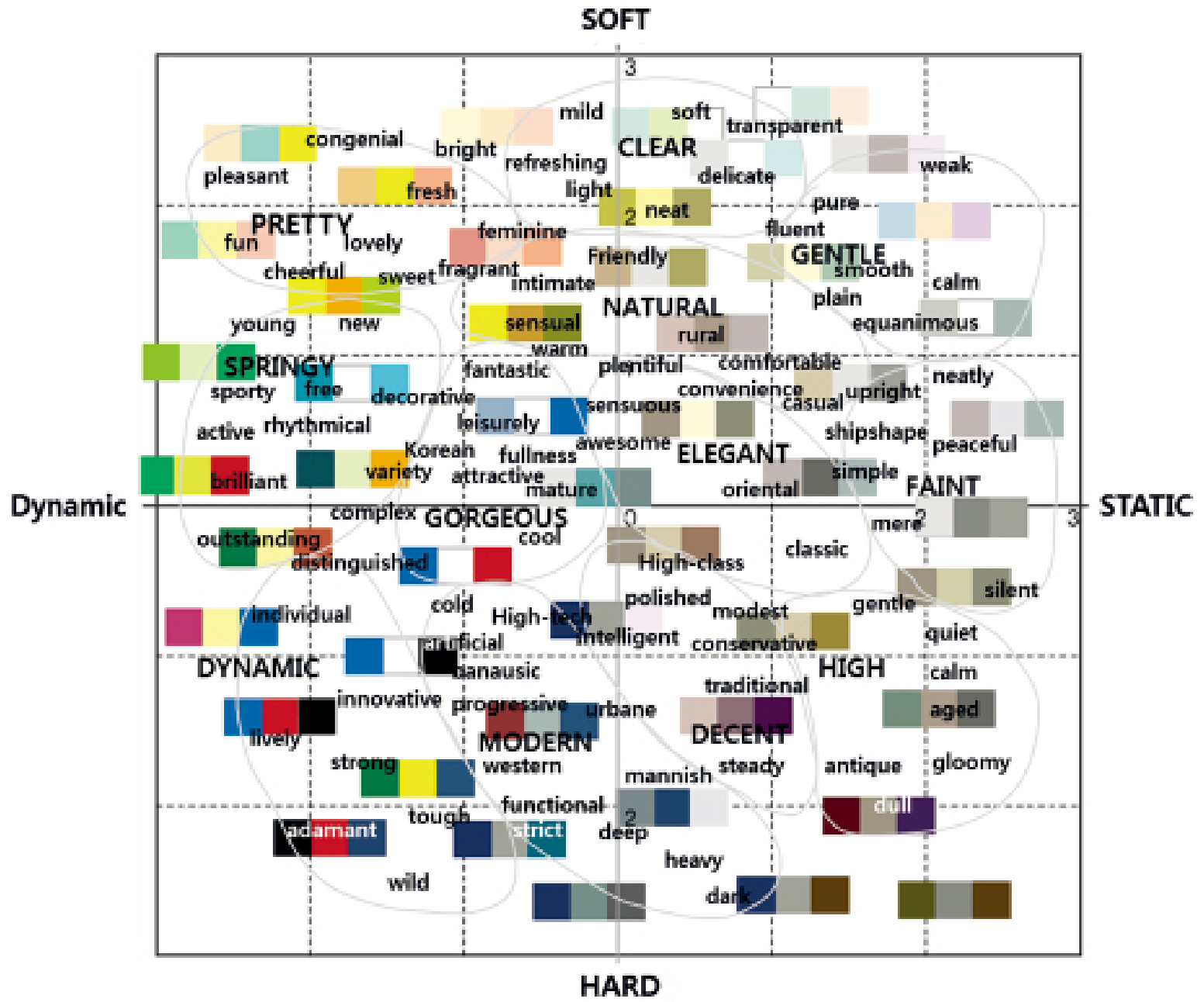

Figure 1. IRI Color Design Institute color image scale.

The scale of images expressed or associated by colors is based on objective statistics. 
준 눈(2d)은 '인공적(40\%)'이며 '현대적인(21\%)'인 느낌이 주를 이루 었다. 블랙의 면적 스모키 메이크업의 눈(2e)은 '강한(28\%)', '거친 (20\%)', '와일드한(8\%)'의 다이나믹 한 이미지로 평가되었다(Figure 2). 전반적으로 표준눈 형태에 스모키 메이크업 톤을 변화한 감성은 부드러운 이미지에서 딱딱한 이미지로 변화하였다.

처진 눈(1a)은 '우울한(97\%)' 부정적인 이미지가 지배적이었다. 반 면 세미 스모키 메이크업을 한 처진 눈(1b)은 '정적인(68\%)' 이미지가 주를 이루고 있었으며 '단순한(25\%)', '우울한' 이미지도 함께 있는 것 으로 평가되었다. 라인 스모키 메이크업을 한 눈(1c)은 '동양적(49\%)' 이라는 이미지가 강하나 처진 눈의 이미지인 '우울한' 이미지도 $24 \%$ 나 되었다. 브라운 톤의 면적 스모키 메이크업 눈(1d)은 '탁한 또는 답답한(78\%)' 이미지와 더불어 '우울한', '슬픈' 등의 이미지로 평가되
었고, 블랙의 면적 스모키 메이크업 눈(1e)은 '어두운(66\%)'과 '무거 운(19\%)' 이미지로 평가되었다(Figure 2). 처진 눈에 스모키 메이크 업 톤을 변화했을 시 변화 감성의 폭은 작았다.

올라간 눈(3a)은 '매력적인(42\%)' 눈으로 평가되었으며, 그 외에 도 '선명한', '현대적', '고양이 이미지', '화려한' 등의 이미지를 갖는 것 으로 평가되었다. 올라간 눈의 세미 스모키 메이크업(3b)은 '도시적 (41\%)', '서양적(19\%)', 및 '지적인(10\%)' 이미지, 라인 스모키 메이 크업(3c)은 '차가운(49\%)'과 '인공적인(24\%)' 이미지, 브라운 톤의 면 적 스모키 메이크업(3d)은 '현대적인(32\%)'과 '강한 (26\%)'이미지가 주를 이루며 그 이외에 '섹시한', '화려한', '개성적인' 이미지 등 다양 한 이미지 들이 있는 것으로 평가되었다. 블랙의 면적 스모키 메이크 업(3e)은 '와일드한'(25\%), '거친'(22\%), '강한'(10\%), 및 '그로데스크

\section{SOFT}

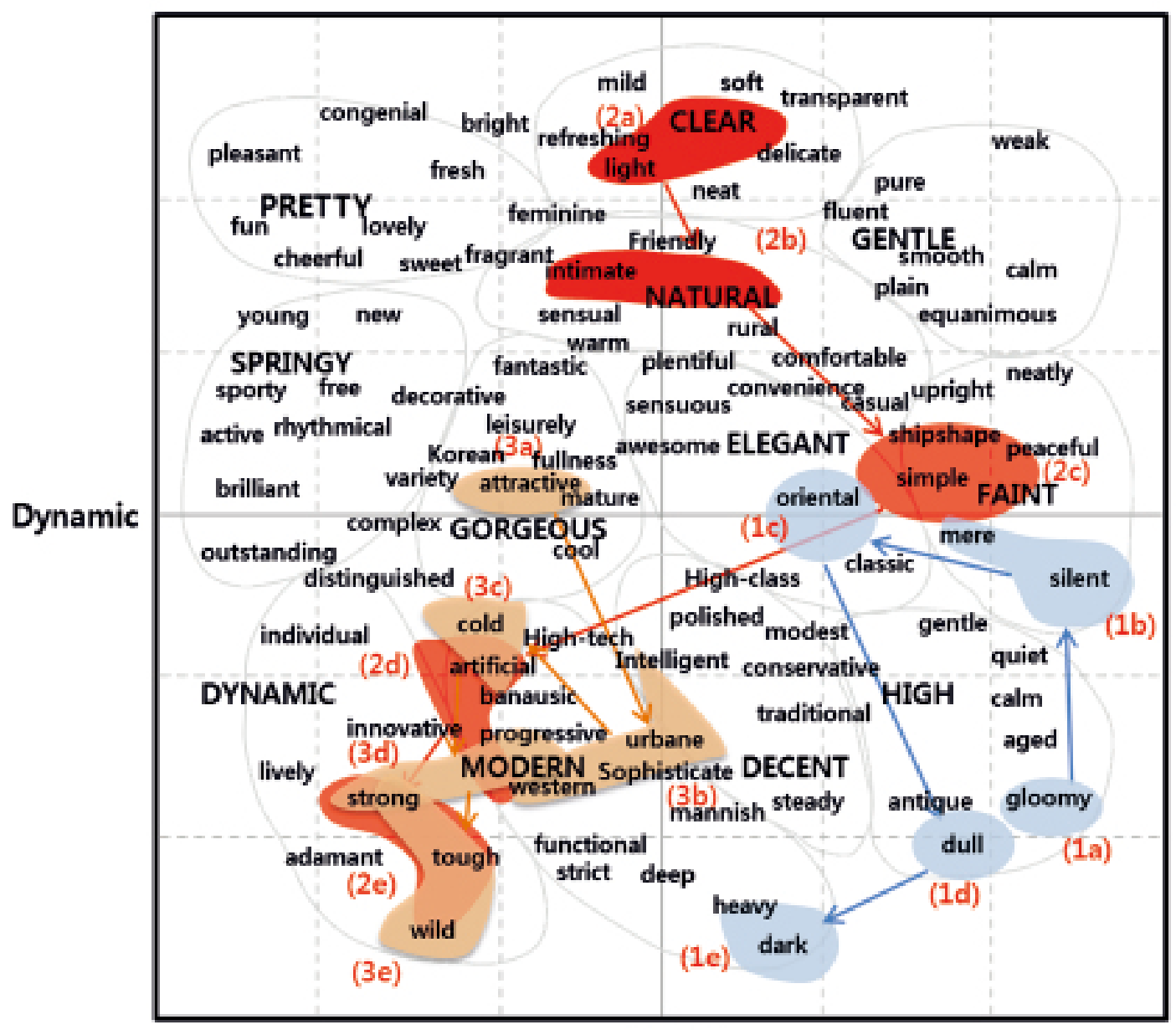

STATIC

HARD

Figure 2. Down-turned eye with double lid and up-turned eye with double lid images induced by smoky makeup.

Down-turned eye $(1 a-1 e)$, standard eye with double lid $(2 a-2 e)$, and up-turned eye $(3 a-3 e)$. Based on the standard, the emotional evaluation of changes in eye tails(down-turned eye with double lid, up-turned eye with double lid)was positioned on the adjective image scale map. The whole face images can be understood from the adjective image map, based on changes in images according to changes in eye shadow tones. 
(grotesque)'적인 이미지를 갖는 것으로 평가되었다(Figure 2). 올라 간 눈에 적용한 스모키 메이크업은 톤의 변화에 따라 활동적 이미지 에서 딱딱한 이미지로 변화하였다.

\section{2. 표준형, 쌍겹의 작은 눈과 큰눈의 감성 이미지}

표준눈을 기준으로 눈의 크기 변화를 주어 작은 눈( $5 \mathrm{a}-5 \mathrm{e})$, 큰 눈 $(7 \mathrm{a}-7 \mathrm{e})$ 에 따른 연상 이미지를 Figure 3 에 도시하였다. 작은 쌍겹눈 (5a)은 '은은한(60\%)'과 '정적인(20\%)'의 느낌으로 전체적으로 은은 한 이미지로 평가되었다. 작은 쌍겹눈의 세미 스모키 메이크업(5b) 은 '그윽한(49\%)', '은은한(22\%)' 및 '심플한(8\%)' 이미지로, 라인 스 모키 메이크업(5c)은 '세련된(22\%)', '동양적인(17\%)', 및 '품위 있는 (16\%)'의 이미지로, 브라운 톤의 면적 스모키는 '도시적인(47\%)'과 '
남성적인(18\%)'인 이미지로, 블랙 면적 스모키는 '무거운(36\%)', '깊 은(22\%)', '어두운(16\%)' 이미지로 평가되었다.

큰 쌍겹눈(7a)은 '밝은(37\%)'과 '맑은(18\%)' 이미지, 그 외에 싱싱 한 이미지로 평가되었다. 큰 쌍겹눈의 세미 스모키 메이크업(7b)은 ' 율동적인(42\%)', '장식적인(14\%)', '스포티한(10\%)' 등으로 전체적으 로 활동적인 이미지로 표출되었고, 라인 스모키 메이크업(7c)는 '시 원한(62\%)', '화려한(19\%)', 및 '차가운(10\%)' 등의 이미지로, 브라운 면적 스모키 메이크업(7d)은 '강한(58\%)', '강인한(17\%)', '거친(4\%)' 이미지로, 블랙 면적 스모키 메이크업(7e)은 '무거운(38\%)'과 '어두운 (37\%)'의 이미지로 평가되었다. 전체적으로 쌍겹눈은 눈 크기와 무 관하게 스모키 톤이 고명도에서 저명도로 변화함에 따라 부드러운 이미지에서 딱딱한 감성으로 변화되었다. 작은 눈은 딱딱한 이미지

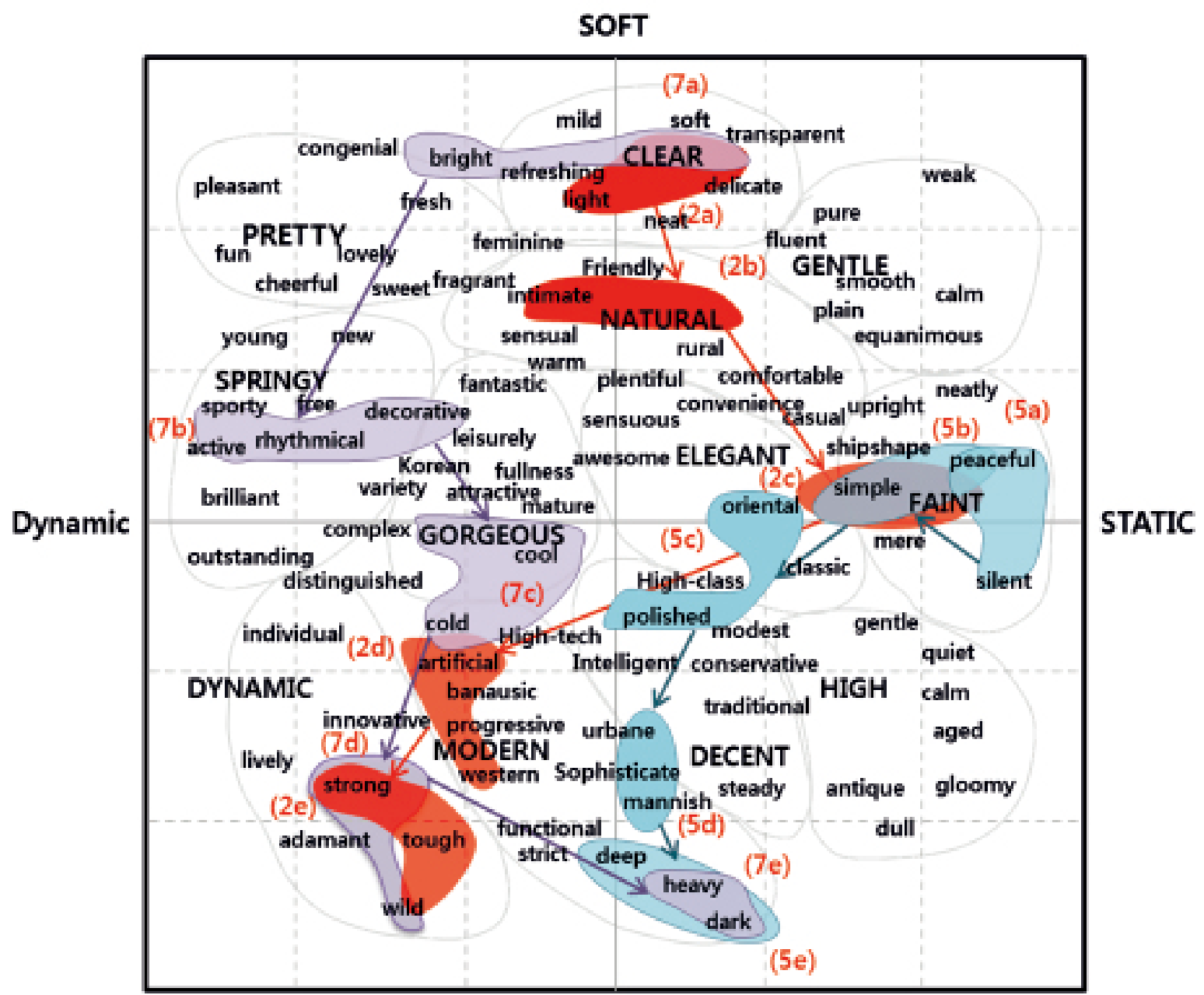

HARD

Figure 3. Small eye with double lid and big eye with double lid images induced by smoky makeup.

Standard eye with double lid ( $2 a-2 e)$, small eye with double lid $(5 a-5 e)$, and big eye with double lid (7a-7e). Based on the standard, the emotional evaluation of changes in eye tails(small eye with double lid, big eye with double lid) was positioned on the adjective image scale map. The whole face images can be understood from the adjective image map, based on changes in images according to changes in eye shadow tones. 
를 가지지만 표준 눈 이상의 크기에서는 부드러운 이미지에서 딱딱 한 이미지까지 다양한 이미지의 연출이 가능하였다.

\section{3. 외겹의 작은 눈과 큰 눈의 감성 이미지}

외겹 눈 중 표준 눈을 기준으로 상대적으로 작은 눈(4a-4e)과 큰 눈(6a-6e)을 대상으로 5가지 톤의 스모키 메이크업을 한 일러스트 레이션들의 연상 이미지를 Figure 4에 정리하였다. 작은 외겹 눈(4a) 은 '매력적(31\%)' 또는 '한국적인(21\%)' 인 이미지를 갖는 것으로 평 가되었다. 작은 외겹 눈의 세미 스모키 메이크업(4b)은 '동양적인 (29\%)', '심플한(23\%)' 이미지, 라인 스모키 메이크업(4c)은 외겹 눈 자 체가 날카로운 형태로 '세련된(38\%)', '보수적인(27\%)', '고급스러운 (9\%)' 이미지였다. 브라운 면적 스모키(4d)는 '점잖은(28\%)'과 '전통 적인(15\%)' 이미지 외에 '지적인' 이미지도 내포된 것으로 평가되었
고, 블랙의 면적 스모키(4e)는 '와일드 한(28\%)', '거친(20\%)', 및 '강한 (12\%)' 이미지로 평가되었다.

큰 외겹눈(6a)은 '스포티한(62\%)'과 '젊은(17\%)' 이미지로 평가되었 다. 큰 외겹 눈의 세미 스모키 메이크업(6b)은 '돋보이는(선명한)' 이 미지가 $60 \%$ 로 지배적이었고, 라인 스모키 메이크업(6c)은 '도시적인 (62\%)', '진보적인(10\%)'인 이미지, 브라운 면적 스모키 메이크업(6d) 은 '서양적인(26\%)', '모던한(14\%)', '딱딱한(10\%)', '남성적인(4\%)' 이 미지, 블랙의 면적 스모키 메이크업(6e)은 '무거운(44\%)'과 '어두운 (37\%)' 이미지로 평가되었다. 쌍겹눈과 마찬가지로 눈 크기와 무관하 게 스모키 메이크업의 톤이 고명도에서 저명도로 변화함에 따라 부드 러운 이미지에서 딱딱한 이미지로 변화하였지만, 외겹 눈은 쌍겹눈에 비해 연출이 가능한 이미지가 상대적으로 제한되었다.

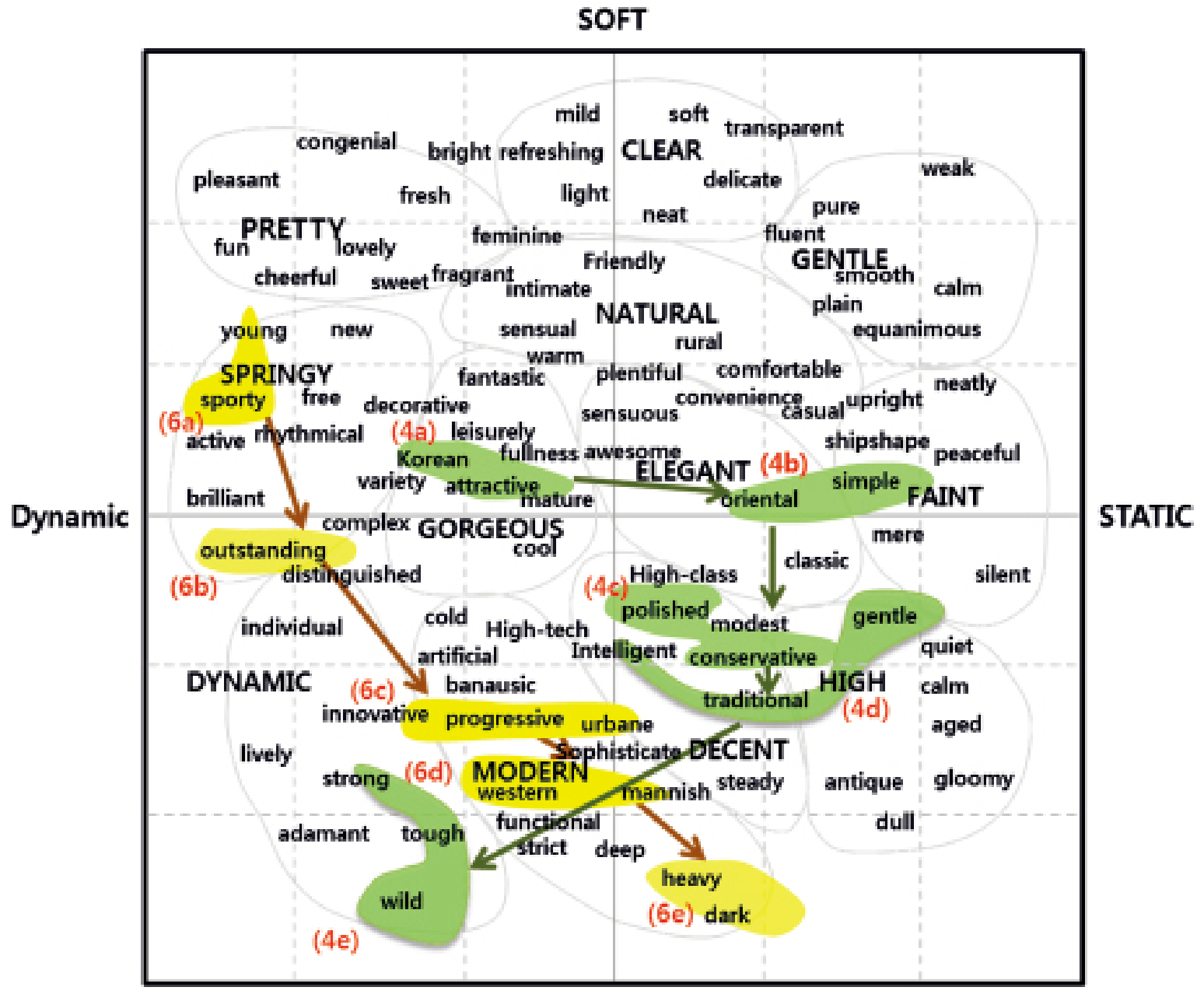

HARD

Figure 4. Small eye with monolid and big eye with monolid images induced by smoky makeup.

Small eye (4a-4e) with monolid and big eye with mono lid (6a-6e). Based on the standard, the emotional evaluation of changes in eye tails (small eye with monolid, big eye with monolid) was positioned on the adjective image scale map. The whole face images can be understood from the adjective image map, based on changes in images according to changes in eye shadow tones. 


\section{Discussion}

눈은 형태에 따라 다양한 이미지가 연상되며, 인종마다 고유한 눈 의 형태를 가지고 있다.

노 메이크업의 표준형 눈(2b)과 쌍겹의 큰눈(7a)은 부드러운 이미 지, 외겹의 작은 눈(4a)과 큰 눈(6a) 및 올라간 눈은 동적인 이미지, 쌍겹의 작은 눈은 정적인 이미지, 처진 눈(1a)은 정적이며 딱딱한 이 미지로 평가되었다(Figure 2-Figure 4).

표준형의 눈(2a)은 맑고 밝은 부드러운 이미지이나 이와 비교하여 상대적으로 눈의 형태가 처지거나 올라가거나, 크거나 작거나, 또는 외겹과 쌍겹 여부에 따라 다양한 이미지로 나타났다(Table 2). 형태
적으로 눈꼬리의 처짐과 올라감에 따라 상당히 대비되는 이미지를 가 지는 것으로 분석되었다. 처진 눈(1a)은 우울해 보이는 이미지를 주 었고, 표준형(2a)의 눈은 밝고 맑은 이미지, 올라 간 눈(3a)은 매력적 인 이미지를 주었다(Figure 2). 즉 눈 꼬리의 위치가 아래에서 위로 올라갈수록 부정적인 이미지에서 긍정적인 이미지와 매력적인 이미 지로 변화한다는 것을 알 수 있었다.

눈의 크기도 이미지 변화에 많은 영향을 미쳤다. 작은 눈에서 큰 눈으로 크기가 변화함 $(5 \mathrm{a} \rightarrow 2 \mathrm{a} \rightarrow 7 \mathrm{a})$ 에 따라 은은하고 정적인 이미지 (5a)에서 맑고 밝은 이미지(2a, 7a)로 변화하였다(Figure 3). 또한 눈 의 이미지는 외겹과 쌍겹에 따라서도 많이 달랐다. 외겹 눈이 동적 인 이미지를 갖는 반면 쌍겹눈은 상대적으로 정적인 이미지를 가졌

Table 2. Classification of images made by smoky makeup

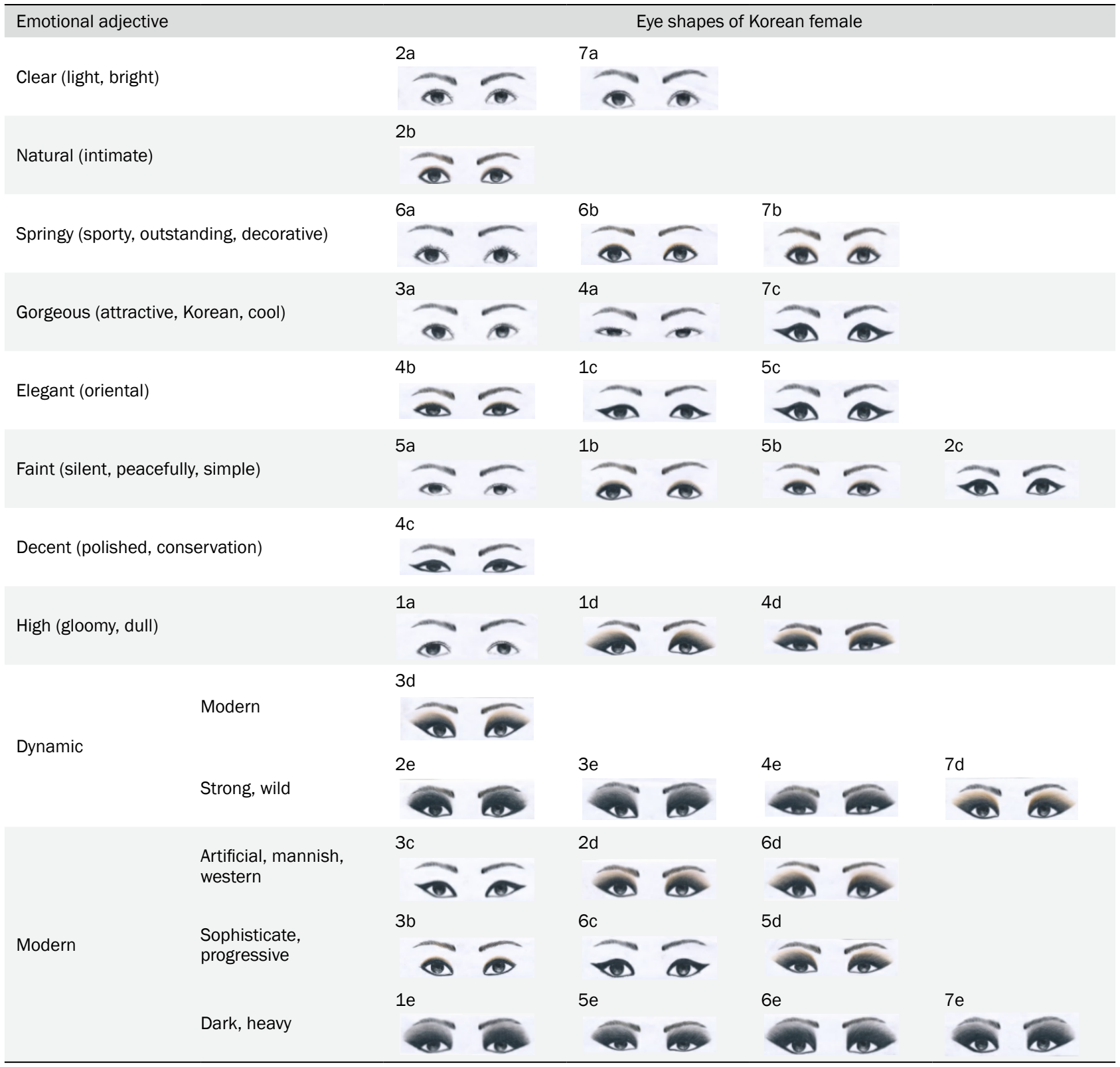


다(Figure 3, Figure 4). 다른 연구에서도 유사한 경향으로 작은 외겹 눈은 소극적이며 답답한 이미지, 표준 눈(보통 크기)은 총명하고 부 드러운 이미지, 큰 눈은 부드러우며 동적이며 진취적이며 감성이 풍 부한 이미지가 연상된다고 하였다(Song et al., 2005).

스모키 메이크업에 의해 연출할 수 있는 눈의 이미지는 형태 에 따라 고유한 이미지 영역을 가지는 것으로 파악되었다(Figure 2-Figure 4), 스모키 메이크업에 의한 가장 뚜렷한 이미지 변화의 방 향은 메이크업 톤을 고명도에서 저명도로 변함에 따라 부드러운 이미 지에서 딱딱한 이미지로 바뀌었다. 이미지 맵에서 노 메이크업 눈의 위치에 따라 그 눈의 다양한 이미지 영역이 표현되기도 하였고, 한정 된 이미지 영역만이 표현되기도 했다. 각각의 눈에 노 메이크업일 경 우 이미지가 부드러웠으나(이미지 맵 상단에 위치) 각각의 눈에 스모 키 메이크업의 톤을 고명도에서 저명도로 변화시킴에 따라 딱딱한 이미지로(이미지 맵의 하단에 위치) 변화되면서 다양한 이미지 영역 의 표현이 가능하였다(표준 눈, 쌍겹 큰 눈). 반면 이미지 맵의 중간 영역에 위치하는 눈(올라간 눈(3a), 외겹 작은 눈(4a)과 쌍겹 작은 눈 (5a))은 딱딱한 이미지였다. 내려간 눈은 메이크업 톤을 변화시켜도 한정적인 이미지만 연출이 가능하였다(Figure 2). 특히 이미지 맵의 하단 부위에 위치하는 딱딱한 이미지의 처진 눈(1a)은 고명도에서 중 명도로 변화함에 따라 딱딱한 이미지(1a)에서 다소 부드러운 이미지 $(1 \mathrm{~b}, 1 \mathrm{c})$ 로 변화하지만 저명도로 연출함에 따라 다시 딱딱한 이미지 $(1 \mathrm{~d}, 1 \mathrm{e})$ 로 되돌아오게 되어 한정된 이미지만을 갖게 된다.

큰 눈이나 올라간 눈에 스모키 메이크업을 적용할 경우 동적인 이 미지를 가지며 처진 눈이나 작은 눈은 상대적으로 정적이면서 딱딱한 이미지를 주로 가진다(Figure 2-Figure 4). 외겹 눈과 쌍겹 눈의 이 미지를 비교하면, 큰 눈은 외겹보다는 쌍겹의 눈이 상대적으로 부드 러우며 정적인 이미지를 가지며, 고명도에서 저명도로 변화함에 따 라 두 눈 간의 이미지 차이는 감소하고 동적 이미지에서 정적 이미지 로 변화된다(Figure 3, Figure 4). 큰 눈과 달리 작은 눈의 경우 중명 도 스모키 메이크업의 외겹(4b-4c)과 쌍겹 $(5 b-5 c)$ 의 이미지와 유사 하다. 7 가지 눈 형태에 스모키 메이크업 일러스트레이션을 적용하여 연상되는 이미지는 Table 2 와 같다. 고명도인 노 메이크업의 눈은 맑 고 가볍고( $2 \mathrm{a}, 7 \mathrm{a})$, 경쾌한(6a), 화려한(3a), 은은한(5a) 이미지로 주 로 표현되었고, 중명도인 소프트와 라인 스모키는 네츄럴하고(2b), 경쾌한( $6 \mathrm{~b}, 7 \mathrm{~b})$, 우아한(4b, 1c, 5c), 은은한(1b, 5b, 2c), 점잖은(4c), 차가운 $(7 \mathrm{c})$ 이미지를 보였다. 저명도인 브라운 톤의 면적 스모키는 고상한(1d, $4 \mathrm{~d})$, 다이나믹(7d), 모던한( $2 \mathrm{~d}, 3 \mathrm{~d}, 5 \mathrm{~d}, 6 \mathrm{~d})$ 이미지였고 블랙톤의 저명도 스모키는 강하고 와일드 $(2 \mathrm{e}, 3 \mathrm{e}, 4 \mathrm{e})$ 하거나 어두우 며 무거운(1e, $5 \mathrm{e}, 6 \mathrm{e}, 7 \mathrm{e})$ 이미지를 보였다(Table 2).

Figure 2-Figure 4에서의 스모키 메이크업에 의해 추출된 컬러 이미지 스케일은 메이크업과 톤 변화에 의해 느껴지는 감성을 체계적 으로 분석할 수 있는 유용한 도구임을 알 수 있다. 본 연구에서 사용 한 이미지 스케일은 한국인의 감성을 기본으로 구축한 것으로 문화권 별로 감성 이미지 스케일은 조금씩 다르다(Lee et al., 2012). 따라서
동일한 메이크업이더라도 느끼는 이미지는 문화권에 따라 다를 수 있 기 때문에 Kobayashi (1981)가 제시한 컬러 형용사 이미지 스케일은 색상으로 인한 것 보다 톤이 세부적인 이미지를 변화시키는 데 더 중 요한 변수였고 톤에 따른 이미지는 채도가 중간 이하로 낮은 경우에 는 모든 색에서 감성반응이 비슷하게 나타났다. 스모키 메이크업 톤 은 밝은 톤이 부드럽고, 정적인 이미지였고, 어두운 톤은 동적이고 딱딱한 이미지였다. 전반적으로 스모키 메이크업의 이미지는 톤 변 화에 많은 영향을 받아서 어두운 톤의 메이크업은 딱딱한 이미지를 보였다(Table 2). 그러나 메이크업 톤이 밝은 경우에는 톤 보다는 눈 의 형태적 특징 $(1 \mathrm{a}, 3 \mathrm{~b}, 3 \mathrm{c}, 6 \mathrm{c})$ 에 의하여 이미지 스케일에서의 위치 가 결정되었다.

대부분의 여성들은 메이크업을 통해 여성스럽고, 자연스러우며, 지적이고 세련된, 귀엽고 청순한 이미지를 표현하고자 하고(Heo, 2005), 남성들은 맑고, 귀여우며, 온화한 이미지의 여성을 선호했다 (Kim, 2011). 아이 쉐도우 톤을 고명도로 시연할 경우 맑고 귀여우며 여성스러운 이미지를 연출할 수 있을 것이며(Jin \& Choi, 2009) 반대 로 아이 쉐도우의 톤이 어두운 면적 스모키의 경우 무겁고 어두우며 강하며 딱딱한 거친 이미지의 표현이 가능하였다. 노 메이크업 눈에 서 느끼는 이미지는 본래의 생김새 그대로 반영되지만, 톤과 색조가 부여되면 눈의 크기가 다르게 보이는 착시 효과뿐만 아니라 이미지도 쉐도우 색상에 따라 다르게 보이게 되었다. 강한 음영을 주었을 경우 눈의 형태가 더욱 또렷하고 크게 보이므로(Seol, 2008) 영화나 연극 등에서 섹시한 이미지 또는 악역으로 보이도록 하거나 파격적이고 도 발적이며 과감한 이미지 변신을 할 때 검고 진한 저명도의 아이 메이 크업을 사용할 수 있다(Hong \& Lee, 2009). 이처럼 메이크업의 톤을 고명도에서 저명도까지 변화시켜 다양한 이미지의 연출할 수 있을 것 이다. 그러나 본 연구 결과들이 제시하는 바와 같이 눈의 형태에 따 라 고유의 이미지 영역이 존재하기 때문에 단순히 일반적으로 알려져 있는 것처럼 아이 쉐도우 메이크업의 톤과 색상의 변화만으로 특정 이미지를 연출하는 것은 매우 어려운 일이다. 본 연구에서 제시한 눈 에 대한 형용사 이미지 scale은 메이크업을 배우는 초보자들이 눈 형 태별로 스모키 메이크업의 톤 변화에 따라 연출되는 이미지의 변화를 이해하고, 눈의 형태에 따라 표현하고자 하는 이미지를 찾는데 유용 한 자료로 활용이 가능할 것으로 판단된다.

\section{Conclusion}

여성들의 7 가지 눈의 형태를 대상으로 스모키 메이크업의 톤 변화 에 따라 연상되는 이미지를 전문가와 비전문가를 대상으로 정형화하 였다. 표준눈, 쌍겹의 큰눈과 같이 노 메이크업 눈의 이미지가 부드 러울수록 스모키 메이크업에 의해 연출할 수 있는 이미지는 부드러 움(맑고, 밝은)에서 딱딱함(강한, 와일드한, 어두운, 무거운)까지 매 우 다양하게 연출할 수 하였다. 그러나 노 메이크업 눈 이미지가 처 
진 눈처럼 자체 이미지가 딱딱하면 스모키 메이크업에 의해 연출할 수 있는 이미지는 매우 제한적이었다. 스모키 메이크업을 적용한 각 각의 눈형태에서 도출된 감성은 눈 자체의 고유한 형태 특성에 영향 을 많이 받았다. 그리고 여러 형태의 눈에 스모키 메이크업 톤 변화 에 의한 감성은 컬러 이미지 스케일에 적용하여 체계적으로 스모키 이미지 맵을 구축할 수 있었다. 이러한 결과는 아이 쉐도우 메이크 업의 톤과 색상 변화만으로 특정 이미지를 연출하는 것이 매우 어렵 다는 것을 의미하였다. 본 연구에서 구축한 이미지 맵은 눈 형태별 로 스모키 메이크업에 따라 연출되는 이미지 변화에 대한 정보를 제 공할 뿐 만 아니라, 메이크업에 의해 표현(또는 연출)할 수 있는 이미 지 영역의 차이가 크다는 것을 파악할 수 있었다. 그리고 image map 은 메이크업 톤 변화에 따른 눈 이미지 변화의 거동특성(dynamic characteristics)을 체계적으로 분석이 가능한 유용한 도구임을 확인 하였다.

\section{Acknowledgements}

본 연구는 2021년도 장안대학교의 연구비 지원으로 수행된 것 으로 이에 감사드립니다.

\section{Author's contribution}

KMK designed all experimental investigations. KMK is conducting an experiment by herself, analyzing data and writing a paper.

\section{Author details}

Min-Kyung Kim (Professor), Department of Beauty Care, Jangan University, 1182 Samcheonbyeongma-ro, Bongdam-eup, Hwaseong-si, Gyeonggi-do 18331, Korea.

\section{References}

Cho MJ. Analysis of image makeup using color trends. Asian Journal of Beauty and Cosmetology, 16: 499-507, 2018.

Choi EM, Yang JS, Kim YM, Lee YJ, Kim KY. A study on suitable makeup and hairstyle for round shape face woman. Journal of Investigative Cosmetology, 6: 15-24, 2010.

Heo SD. The effect of image make-up on the formation of physiognomy: centering around seven kinds of face. The Journal the Korean Society of make-up Design, 1: 79-92, 2005.

Seol HJ. A study on the eye make-up though color contrast. Journal of the Korean Society of Beauty and Art, 23: 65$78,2008$.
Hong SN, Lee SE. Research on mutual relativeness between femme fatale image and smoky makeup: highlighted on Korea popular star. Journal of the Korean Society of Beauty and Art, 10: 25-41, 2009.

Ji HS, Kim ES. A study on the color coordination of eye-shadow makeup-focused on works of kendra stanton in makeup of "daytime to night", "special occasion", "holiday accents", "seasonal looks" and "animated characters. Fashion \& Textile Research Journal, 18: 509-519, 2016.

Jin HY, Choi HJ. A case study on the application of an image making: focused on Korea women age around 20-30. The Journal the Korean Society of Make-up Design, 5: 29-38, 2009.

Kim EH. A study on the makeup of Korean boy idol groups: focusing on active boy idol groups in 2017. The Journal of the Korean Society of Make-up Design, 14: 1-10, 2018.

Kim MK, Ryu HW. Analysis of emotional images according to eyes shapes and smoky makeup tone. Korean Journal of the Science of Emotion \& Sensibility, 14: 321-330, 2011.

Kim JS. A study on the characteristics of make-up revealed in fashion collections and advertisements: focused on smoky make-up in 2000's. Journal of The Korean Society of Cosmetology, 15: 766-776, 2009.

Kim YS. A study on make-up image and color preferred by men of 20s 30s. Journal of Korea Society of Color Studies, 25: 55-66, 2011.

Kim MK, Hong SK. Make-up design book. Chung gu Munhwasa, Soul, pp25-26, 2010.

Kim JL, Choy HS. Characteristics of subculture style makeup in fashion collections. Journal of Fashion Design, 12: 39-53, 2012.

Kobayashi S. The aim and method of the color image scale. Color Research \& Application, 6: 93-107, 1981.

Lee MS, Sa JK, Chung KH. A comparative analysis of the characteristics and images of costume colors in the traditional plays of Korea, China, and Japan. Color Research \& Application, 37: 302-312, 2012.

Lee YJ. Lee JH. The development of an emotion model based on colour combinations. International Journal of Consumer Studies, 30: 122-136, 2006.

Oh SH, Choi HJ. A study on the characteristics of makeup by ethnic fashion type. Journal of the Korean Society of Costume, 61: 116-130, 2011.

Park JW, Lee SE, Yi MH. Focused on femme fatale image 
Analysis of Images Produced by Smoky Makeup Using a Color Image Scale

makeup in movies. Journal of Korean Traditional Costume, 10: 113-130, 2007.

Song MY, Park OR, Lee YJ. A study on the face image to shape differences and make up. Korean Journal of Human
Ecology, 14: 143-153, 2005.

Yang YM. A study on smoky makeup expressed modern makeup: focused on romantic and mannish sensibility. Journal of the Korea Design Society, 6: 293-304, 2010. 


\section{국문초록}

\section{여성의 눈 형태에 컬러 이미지 스케일을 이용한 스모키 메이크업 이미지의 분석}

김민경

장안대학교 뷰티케어과, 경기도 화성시, 한국

목적: 눈의 형태에 따라 스모키 메이크업의 톤 변화에 의한 연출 가능한 이미지를 분석하기 위하여 정량적으로 평가하기 위한 도구 로 형용사 이미지 스케일에 적용하여 이미지를 평가하였다. 방법: 여성들의 눈을 7 가지 형태(표준형 눈, 처진 눈, 올라간 눈, 쌍겹의 작은 눈과 큰 눈, 외겹의 작은 눈과 큰 눈)로 분류하여 전문가와 미용학과 여자 대학생 342 명을 대상으로 스모키 메이크업의 톤을 고명도에서 저명도까지 5 단계로 변화시킨 일러스트레이션들의 이미지를 조사하였다. 결과: 노 메이크업 눈(eyes without makeup) 은 쌍겹의 표준형 눈과 큰 눈은 동적이고 부드러운 이미지를, 처진 눈은 정적이고 딱딱한 이미지로 평가되는 등 눈의 형태에 따라 다양한 이미지를 가졌다. 그리고 image map에서의 각각의 눈의 위치는 눈의 형태에 따라 달라졌다. 가장 부드러운 이미지를 가진 것으로 평가된 표준형의 눈은 스모키 메이크업의 톤을 변화시켜 매우 다양한 이미지들의 표현이 가능하였지만, 처진 눈은 스모키 메이크업의 톤을 변화시켜도 표현할 수 있는 이미지는 한정적이었다. 결론: 눈의 형태에 따라 메이크업에 의해 연출할 수 있는 이미 지 영역의 차이가 크다는 것과 image map은 메이크업 톤 변화에 따른 눈 이미지 변화의 거동특성(dynamic characteristics)을 체계 적으로 분석이 가능한 유용한 도구임을 확인하였다.

핵심어: 컬러, 이미지 스케일, 눈의 형태, 스모키 메이크업, 이미지

본 연구는 2021년도 장안대학교 연구비 지원으로 수행된 것으로 이에 감사드립니다.

\section{참고문헌}

김민경, 류희욱. 눈 형태에 따른 스모키 메이크업 감성 이미지. 감성과학, 14: 321-330, 2011.

김민경, 홍수경. Make-up Design Book. 청구, 서울, pp25-26, 2010.

김영숙. 20 30대 남성이 선호하는 여성의 메이크업 이미지와 색채에 관한 연구. 한국색채논문집, 55-66, 2011.

김의형. 한국 남성 아이돌 그룹의 메이크업 분석: 2017년 활동 중인 남성 아이돌을 대상으로. 한국메이크업디자인학회지,

14: 1-10, 2018.

김정시. 패션컬렉션 및 광고 메이크업의 표현특성에 관한 연구: 2000년대 스모키 메이크업을 중심으로. 한국미용학회지,

15: 766-776, 2009.

김지량, 최현숙. 패션 컬렉션 메이크업에 나타난 하위문화스타일메이크업 특성. 한국패션디자인학회지, $12: 39-53$, 2012.

박정원, 이상은, 이미희. 영화에 나타난 팜므파탈 이미지 메이크업 연구. 한복문화, 10: 113-130, 2007.

설현진. 색채대비를 적용한 아이메이크업 연구. 한국인체미용예술학회지, 9: 65-78, 2008.

송미영, 박옥련, 이영주. 얼굴의 형태적 특성과 메이크업에 의한 얼굴 이미지 연구. 한국생활과학회지, 14: 143-153, 2005.

양윤미. 현대 메이크업에 나타난 스모키 메이크업에 관한 연구: 로맨틱 감성과 매니쉬 감성을 중심으로. 코리아뷰티디자인

학회지, 6: 293-304, 2010.

오세희, 최해주. 에스닉 패션 유형별 메이크업 특성에 관한 연구. 복식, 61: 116-130, 2011.

조미자. 컬러 트렌드를 활용한 이미지 메이크업 분석. 아시안뷰티화장품학술지, 16: 499-507, 2018.

지현숙, 김은실. 아이새도우 메이크업(Eye-shadow Makeup)의 컬러 배색에 관한 연구:켄드라 스탠튼(Kendra Stanton) 
의 "내추럴(Daytime to Night)", "스페셜(Special Occasion)", "할러데이(Holiday Accents)", "시즌(Seasonal Looks)", "캐릭터(Animated Characters)" 메이크업 경우를 중심으로. 한국의류산업학회지, 18: 509-519, 2016.

진형여, 최희자. 이미지 메이킹 적용에 관한 사례연구: 우리나라 20 30대 여성들을 중심으로. 한국메이크업디자인학회 지, 5: 29-38, 2009.

최은미, 양정순, 김유미, 이윤진, 김가영. 둥근형 얼굴에 어울리는 메이크업과 헤어스타일에 관한 연구. 대한미용학회지, 6: 15-24, 2010.

허순득. 이미지 수정 메이크업이 인상형성에 미치는 효과: 7가지 얼굴형을 중심으로. 한국메이크업디자인학회지, 1: 7992, 2005.

홍수남, 이상은. 팜므파탈 이미지와 스모키메이크업의 상호연관성에 관한 연구: 한국의 대중스타를 중심으로. 한국인체미 용예술학회지, 10: 25-41, 2009. 


\section{中文摘要}

\section{用女性眼睛彩色图像标度分析烟熏妆产生的图像}

金玟京

长安大学美容学科, 京畿道华城市, 韩国

目的: 为了分析烟熏妆中色调变化产生的图像, 本研究根据眼睛的形态, 应用形容词图像量表作为定量评估工具 对其进行评估。方法: 通过将女性眼睛分为七种类型, 我们检查了烟熏妆色调在五个阶段发生变化的图像, 从最 高亮度到最低亮度。我们在图像地图上改变了眼睛的位置。结果: 不化妆的眼睛有不同的图像, 这取决于眼睛的 形状 : 标准眼䀦和大眼睛有动态和柔和的图像, 而下垂的眼睛有静态和僵硬的图像。眼睛的位置在图像地图上 是不同的。虽然被评估为具有最柔和图像的标准眼睛可以通过改变烟熏妆的色调来表达非常不同的图像, 但是 那些可以通过下垂的眼睛来表达的图像非常有限, 即使烟熏妆的色调发生了变化。结论: 结果发现, 随着化妆色 调的改变, 化妆产生的图像区域有很大的变化, 图像地图是一种有用的工具, 可以系统地分析眼部图像变化的 动态特征。

关键词: 颜色, 彩色图像比例, 眼睛形状, 图像, 烟熏妆 
